\title{
Currency Crisis: The Case Of Iceland
}

Merouane Lakehal-Ayat, St. John Fisher College, USA

\begin{abstract}
The purpose of this research paper is to analyze the Krona (the Icelandic currency) from an investment perspective while determining what has influenced its recent value deterioration. The paper looks at many different variables that have influenced the currency since the 1980s. These factors include: Iceland's market-based economy, the layout of their financial system, the exchange rate system, balance of payments, international investment position, and the fiscal/monetary policies that influence their society. When investing in this currency, it is vital to understand the importance of each of these factors and their role in the valuation of the currency as an investment. With the recent decline of the Krona's value, recommendations are put forward regarding Iceland's currency's management. Due to the fact that their financial system has been the backbone of their economy over the last decade, they need to stabilize this system first and foremost. As soon as the economy will display signs of recovery, the government must take measures to curb the deficit and external debt, while encouraging the diversification of the Icelandic economy. Moreover, Iceland must do its best to join the Euro zone. In that context and from an investment approach; namely, trading the Krona, individuals should sell it if they have a short-term investment horizon. However, in the long-term ranging from three to five years, the currency promises modest return.
\end{abstract}

Keywords: Krona - Icelandic currency, IMF - International Monetary Fund, EU - European Union, GDP - Gross Domestic Product, BOP - Balance of Payments

\section{INTRODUCTION}

$\mathrm{n}$ the past decade, Iceland has seen a swift rise in the standard of living for its population. The national economy has traditionally been dependant on marine products, such as the fishing industry, but since the early 2000s due to the contraction of the fishing industry, the economy has taken a turn toward diversification and expanded in other areas, such as aluminum exports, and especially the banking industry. Iceland has a highly skilled population and an attractive long-term investment environment.

\section{A MARKET-BASED ECONOMY}

Over the past two decades, significant structural reforms have taken place in the Icelandic economy and financial markets. These reforms have aimed to enhance the role of market forces through deregulation and integration into the world economy. Policies of market liberalization, fiscal consolidation, privatization and other structural reforms were implemented in the late 1980s and early 1990s. Throughout the 1980s and until the late 1990s, Iceland faced periods of negative GDP growth due to contraction in the fishing industry, as well as fiscal/momentary policies aimed at curbing inflation. In addition to domestic factors, the national economy also suffered due to the less-than-desirable global economic conditions at the time. Starting in the 1980s, signs of growth appeared in the fishing industry and the export sector causing a great amount of foreign investment to flow into the aluminum and power sectors. In addition, domestic consumption, which was mostly financed by foreign credit, exploded. These imbalances later exposed the Icelandic economy to many risk factors in global equity and debt markets. In the last 12 years, the fiscal balance has followed the domestic cycle quite closely. A 13-year string of general government deficits came to an end in 1997. During 1997-2001, there was a return to surplus from the impressive economic growth. As the economy weakened in 2002-2003, the surplus turned into deficit. Renewed growth brought back a slight surplus in 2004, which strengthened to 3-4\% of GDP in 2005 despite a cut in personal income taxes. 


\section{THE FINANCIAL SYSTEM}

The financial system consisted of three main banks that were state owned and highly politicized. Until 1980 , the exchange rate was fixed. "The exchange rate peg was adjusted frequently, especially in the 1970s and 1980s, with a view to making average profits in the fishing industry equal to zero"(Danielsson and Zoega, 2009). The rate was set too high, thus preventing many industries from prospering. As part of the deal to join the European Union, Iceland began the process of economic liberalization during the 1990s. Big banks were privatized and exchange rates were allowed to float freely. Accusations rose that the government had favored certain groups throughout the process. Before this happened, the Krona was pegged against the dollar and later against a basket of several currencies as part of an effort to maintain price stability. The peg regime was used as a monetary policy in order to stabilize the fishing industry that made up a major part of Iceland's exports.

After the privatization of the banking system, the few giant banks took on an expansion venture through which they expanded globally. Their assets, as a percentage of GDP, grew from 170\% in 2003 to over $880 \%$ in 2007. They were highly leveraged firms that borrowed enormous amounts of debt from international markets to finance few firms inside Iceland as well as the investment of banks themselves in foreign equity markets. This strategically flawed move exposed banks to the downside of equity risk which had happened after the meltdown in Wall Street. The banks had become too big for the government to support and they had little significance to global markets in order for a global rescue plan to take place.

Starting in 2004, private banks began to increase their share in the mortgage market by offering lower interest with longer maturity loans, most of which did not require a house purchase as a prerequisite to the loan. This was the reason behind the housing bubble as well as the infusion of credit into consumption areas that led to higher inflation until late 2005. In addition, the inflow of investment from abroad, due to the interest rate gap between Iceland and other European states, created a kind of consumption pattern that benefited the import sector while hurting the export industry. The current account experienced enormous deficit with imports sometimes consisting of $16.5 \%$ of GDP in 2005. Graphs 1-4 help explain the currency account deficit as a result of the exchange rate between the Iceland Kronur and the U.S. Dollar.

\section{THE EXCHANGE RATE}

Graph 1 shows historical exchange rates between the Iceland Krona (ISK) and the US Dollar (USD) between 12/20/2009 and 1/18/2010.

\section{Graph 1}

\section{Iceland Kronur (ISK) to 1 US Dollar (USD)}

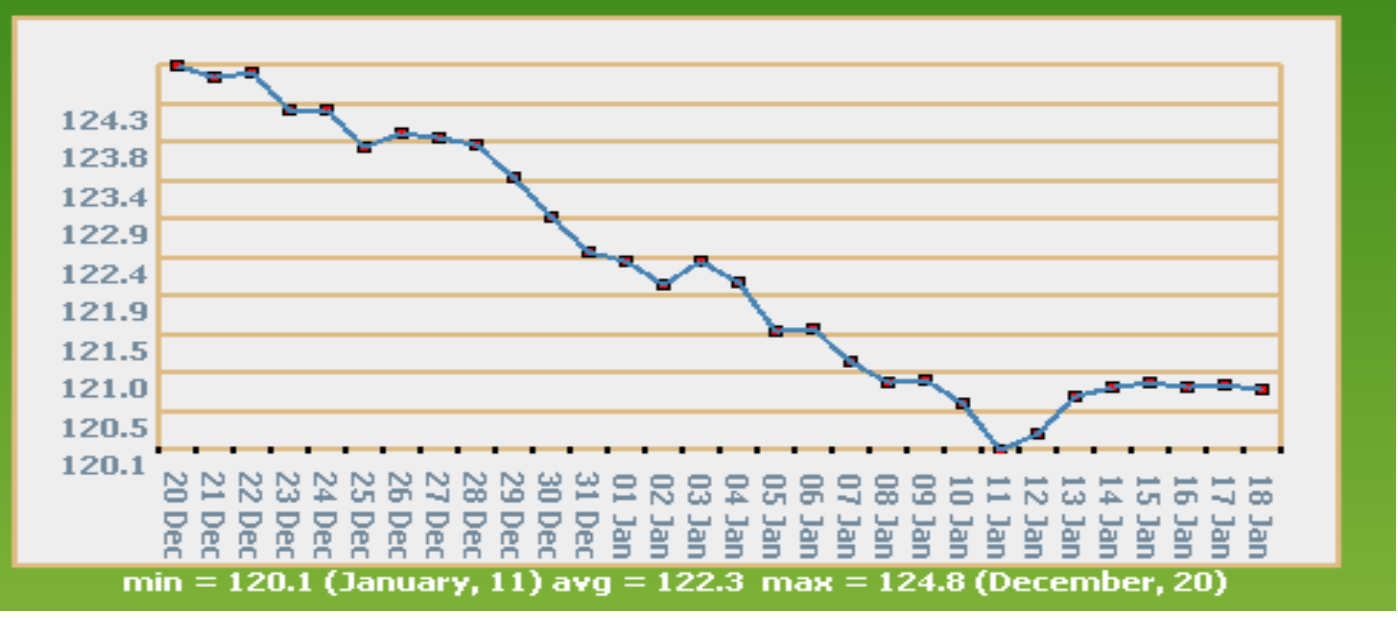


Graph 2 shows historical exchange rates between the Iceland Krona (ISK) and the US Dollar (USD) between 10/21/2009 and 1/18/2010.

Graph 2

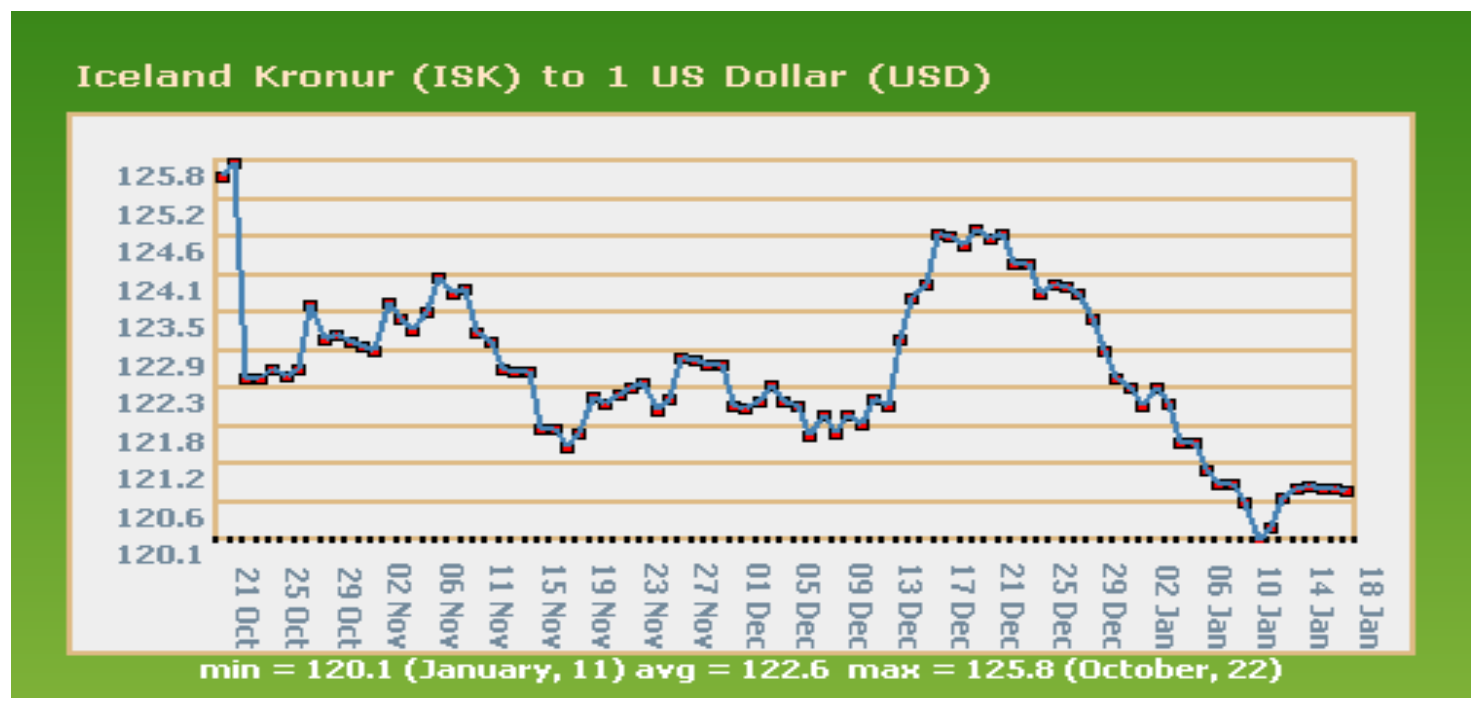

Graph 3 shows historical exchange rates between the Iceland Krona (ISK) and the US Dollar (USD) between $7 / 23 / 2009$ and $1 / 18 / 2010$.

Graph 3

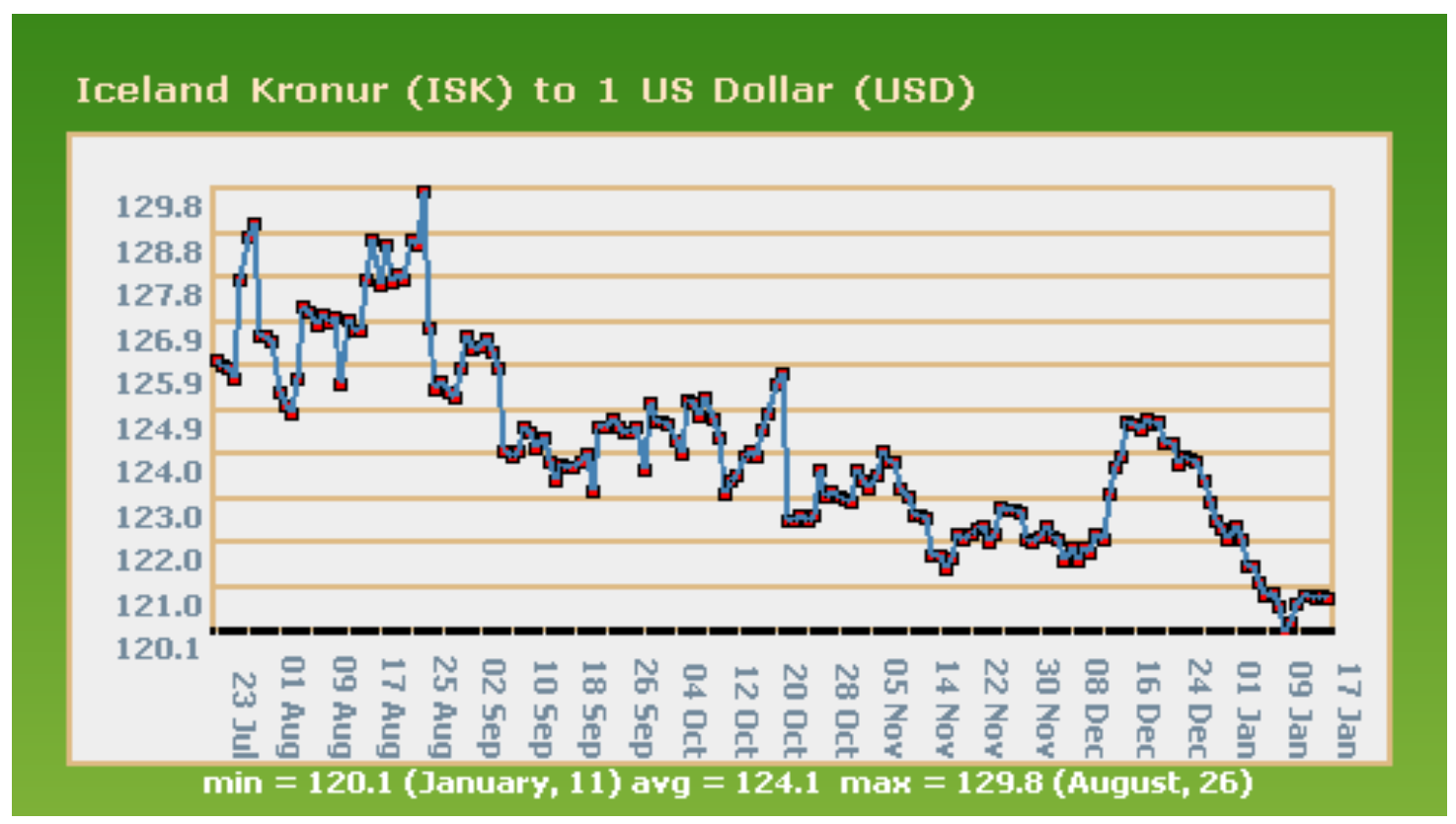


Graph 4 shows historical exchange rates between the Iceland Krona (ISK) and the US Dollar (USD) between $2 / 28 / 2009$ and $1 / 18 / 2010$.

\section{Graph 4}

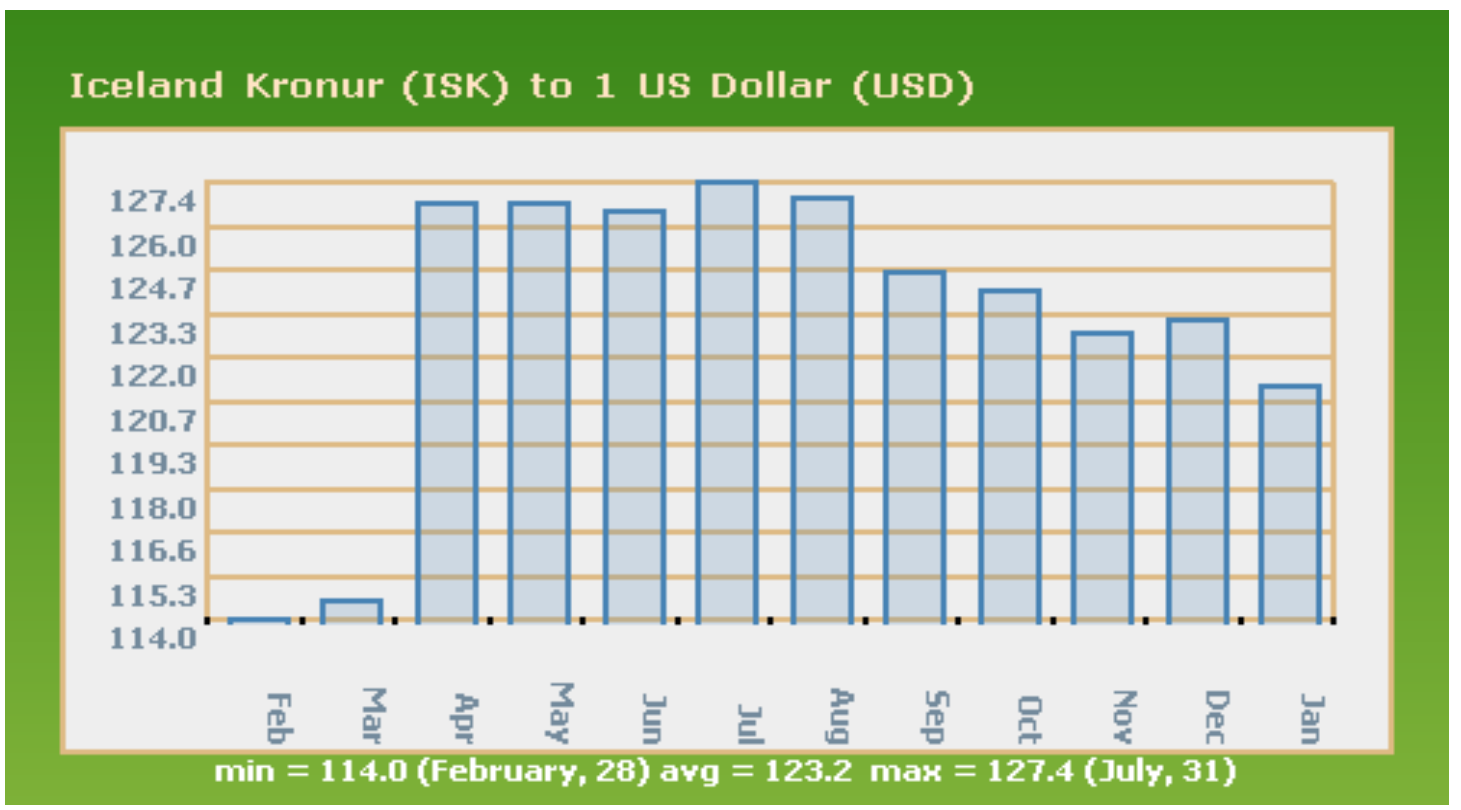

A multi-dimensional approach to Iceland's economic and fiscal conditions will help us better understand the prospects of economic growth as well as the extension of the recession that has hit Iceland since October of 2008 following a crisis in the financial sector. I will begin by analyzing elements of different approaches in the exchange rate determination model. This will also explain the factors that directly and indirectly affect the prices of Icelandic Krona.

\section{BALANCE OF PAYMENTS}

\section{Current Account Balance}

The $4^{\text {th }}$ quarter report on key economic statistics, as well as the BOP reports, are due on March 1, 2010, thus we only have the data from reports on $3^{\text {rd }}$ quarter of 2009 to work with. In that time period, Iceland was running a deficit of $36 \mathrm{~b}$. kr which marks a $29 \mathrm{~b}$ kr lower number than the preceding period. Both the merchandise and service accounts were positive; however, the income account remained negative for yet another quarter due to deposit institutions undergoing winding-up of their proceedings. Still, this indicates a recovery process which may be slower than the public expected. Graph 5 illustrates the overall change of services and goods produced.

\section{INTERNATIONAL INVESTMENT POSITION}

External assets totaled $8,930 \mathrm{~b} \mathrm{kr}$. at the end of the quarter, while external debt totaled 14,669 b.kr. The net external position was therefore negative by $5,739 \mathrm{~b}$ kr. This point is supported by the data found in Graph 6 . 
Graph 5

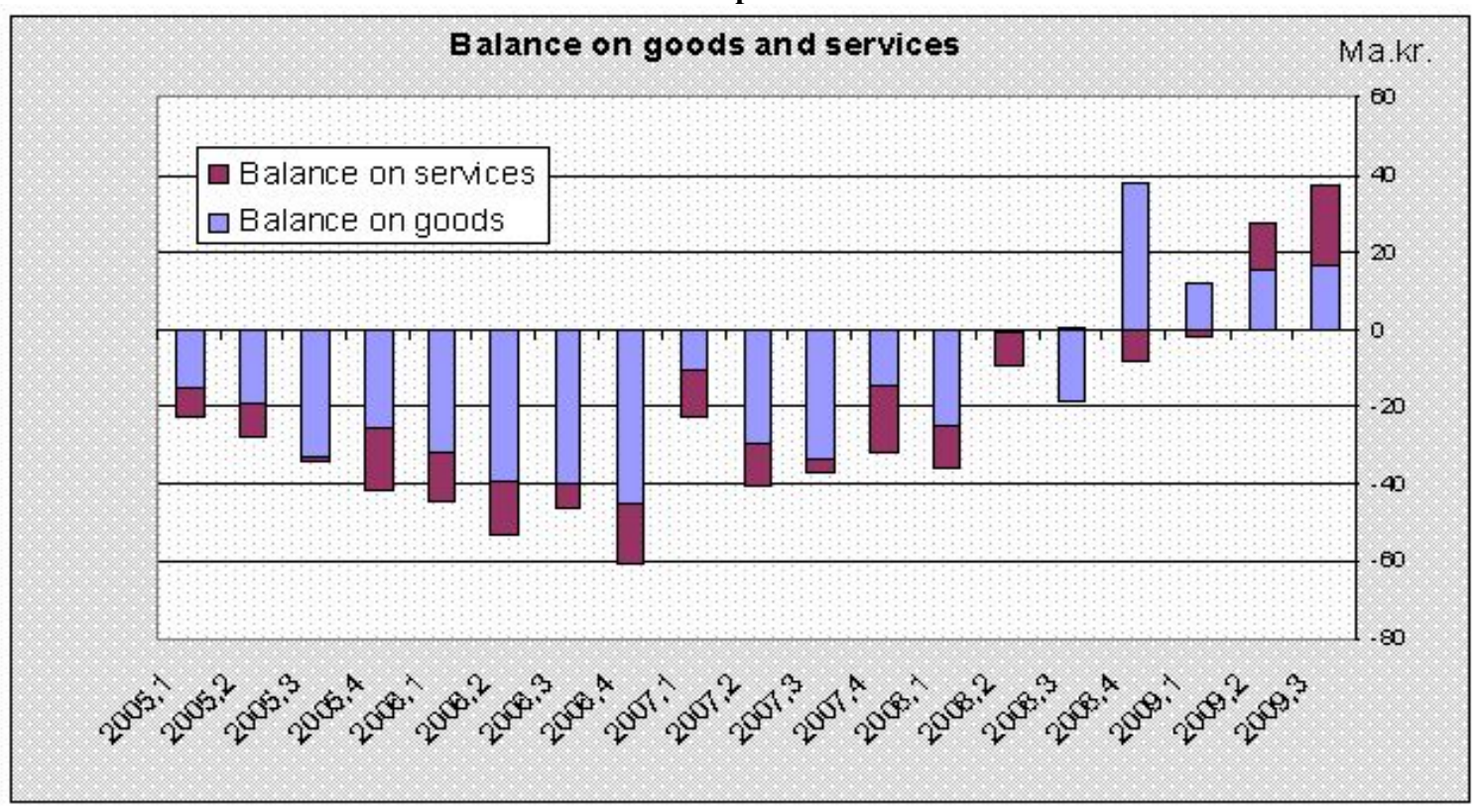

Graph 6

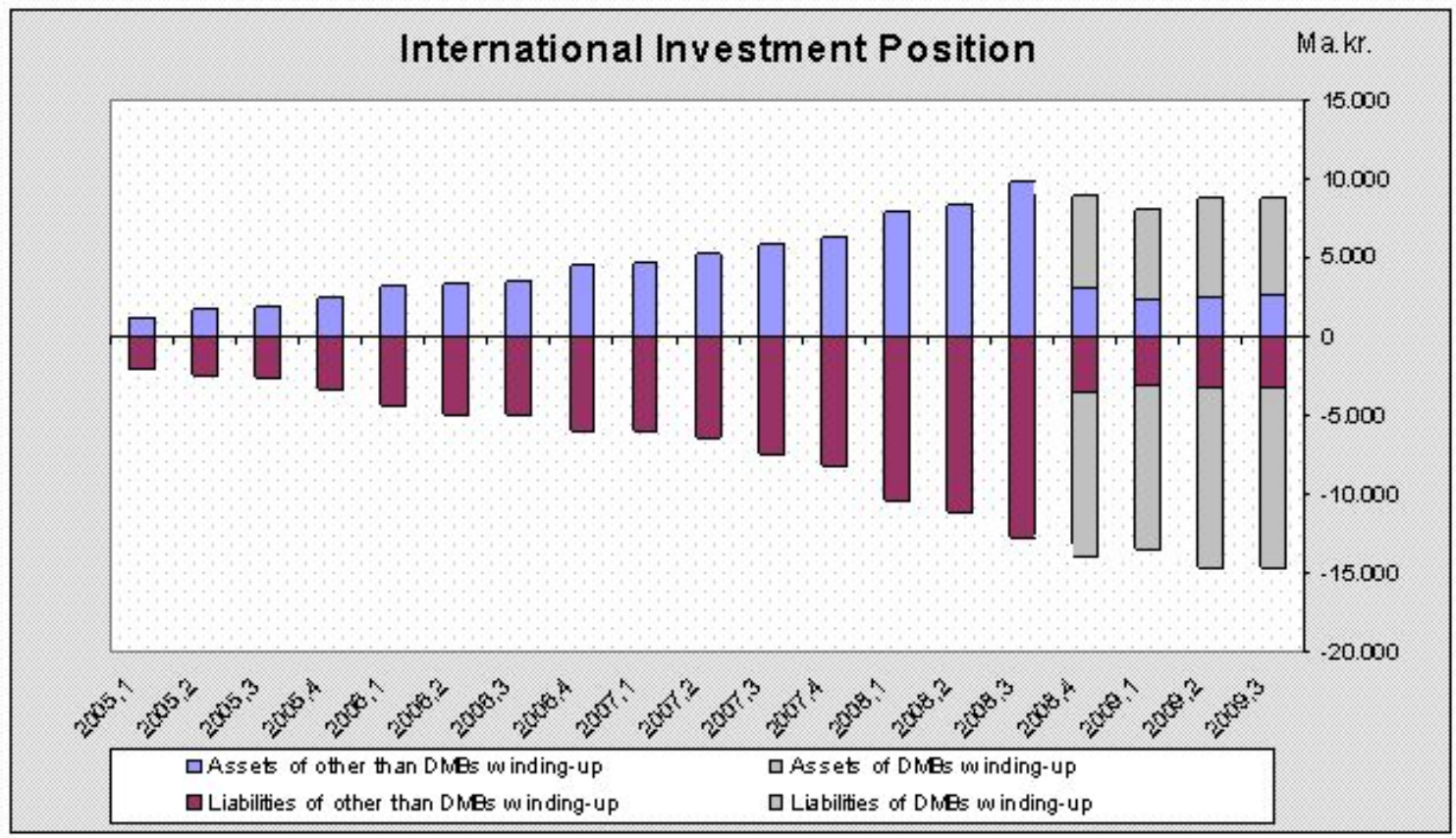

\section{FOREIGN DIRECT INVESTMENT}

The data on foreign direct investment in Iceland pertain to the year 2008 as the reports cover information on a yearly basis; but as the trend indicates, the foreign direct investment shrunk significantly in 2008 compared to 2007 and 2006, thus decreasing the flow of foreign reserves to the country. This has put a strain on the Icelandic Krona while strengthening foreign currencies, especially the Dollar and Euro. As the supply of Dollar and Euro decreased in a time when the Krona was depreciating at a fast rate, the appetite for hard currency grew in the country, putting another wave of downward pressure on the price of the Krona. This lasted for a period before the 
government established certain control rules on banks with regard to currency trading as well as taking other measures on a macro level to stabilize the currency rates. Graph 7 illustrates the trend of foreign direct investment.

Graph 7

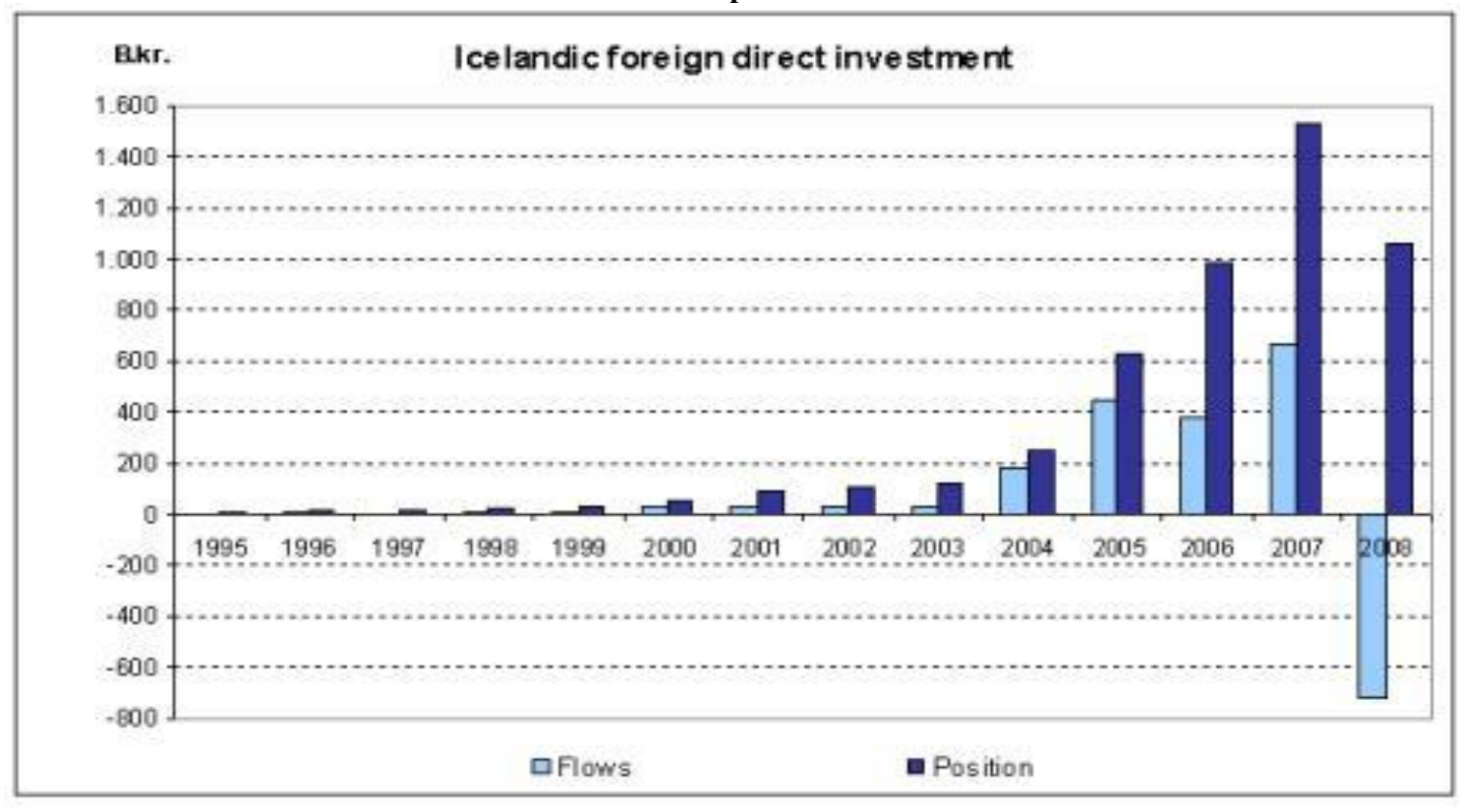

Graph 8

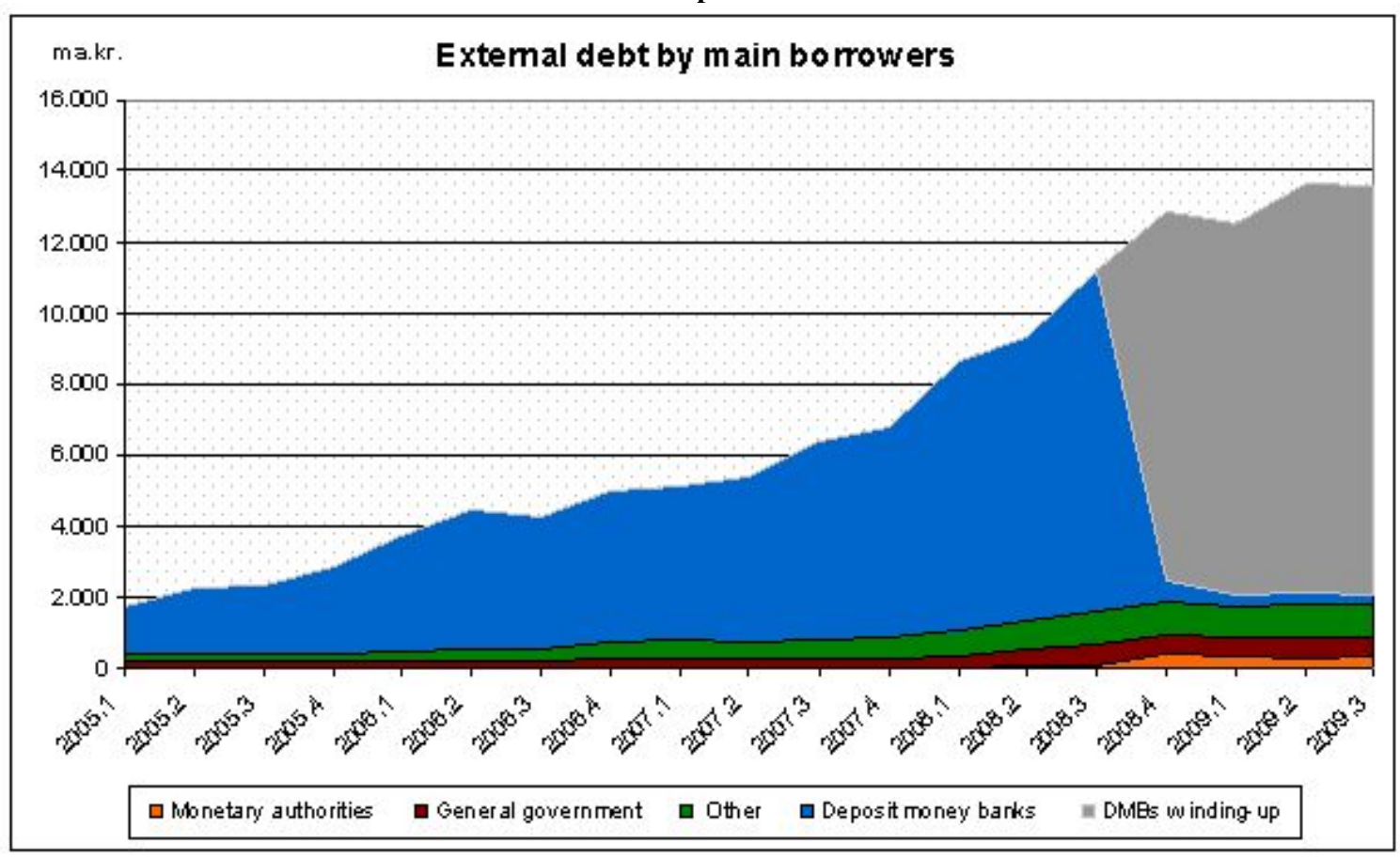




\section{EXTERNAL DEBT}

The external debt at the end of the quarter totaled $15,140 \mathrm{~b} \mathrm{kr}$. Graph 8 indicates the trend of growing external debt in Iceland. It has been both a source of economic growth, as per financing domestic consumption, and also the large amount of external debt has put pressure on the Icelandic economy on two fronts. First, the currency exchange rate has been strained due to the prospect of future interest rate increases to attract further debt. Secondly, the fact that Iceland's government debt has been downgraded by credit agencies makes it more difficult for the country to finance future growth. In addition, the interest rates on foreign debts are accumulating at an exponential rate, forcing the Icelandic government to turn to the IMF for financial support.

In a recent press conference, the IMF mission Chief, Mark Flanagan, expressed optimism regarding the Icelandic economy and explained the debt issue as such: "Iceland's total external debt is expected to peak at about 310 percent of GDP while the gross public debt will peak at around 135 percent of GDP. The external debt figure is much higher than initially appreciated in the aftermath of the crisis". Although he admitted to the high levels of national debt, he said the debt is sustainable. His reasoning behind the optimism with regard to the sustainability of national debt was the idea that as assets are recovered from the failed banks, as the corporate and financial sector debt is written down, and the economy rebounds from crisis, the debt stocks will decrease gradually. He also pointed out to Iceland's significant foreign assets, including those held by the country's fully-funded pension system.

He also mentioned the increasing public debt in Iceland due to government spending which, according to him, helped curtail domestic unemployment. He also argued against the unsustainable nature of public spending in the long run as he explained how Iceland is not facing age related fiscal problems compared to other European countries.

\section{INTERNATIONAL RESERVES}

The official reserves of the Central Bank of Iceland totaled $490.1 \mathrm{~b} \mathrm{kr}$ at the end of December, having increased by $87.3 \mathrm{~b}$ kr between months. The increase is a result of the loan from the Nordic countries, which is a part of the economic program of the Icelandic government and the International Monetary Fund (IMF). In the meantime, foreign securities increased by 1.7 b.kr in December, while currency and deposits increased by $85.5 \mathrm{~b} . \mathrm{kr}$ (refer to Graph 9). The amount of reserves can have a dramatic impact on the ability of Iceland's central bank to make foreign currency available to businesses inside Iceland that trade in foreign currency and require the dollar or euro to continue operations. This can become critical at a time when credit is tight and banks are hesitating to loan. In a situation where a country depends heavily on international trade, having currency reserves of international currencies become vital to prevent a situation, like Argentina, where businesses had to turn to the black market for currency exchange.

Graph 10 breaks down the foreign currency balance of Iceland Central Bank.

\section{ASSET APPROACH}

The recession continues. Domestic demand has fallen significantly and the economy is estimated to continue shrinking until early 2010. Thereafter, economic growth is anticipated to return, boosted initially by the expected normalization in the financial industry and subsequently by investment in large energy-related projects. The unemployment rate will most probably rise to around $7 \%$ by mid-2010 and then gradually come down afterward. According to OECD economic outlook, "The government programs will help to narrow economic imbalances, with inflation falling to about $2 \frac{1}{2} 2$ percent by 2011 and the current account deficit declining to $1 \frac{1 / 2}{2}$ per cent of GDP in $2011 "$.

The fiscal policy must focus on setting public finance on the right path to support domestic growth. In the meantime, the monetary policy must remain focused on exchange rate stability. An important move will be to gradually remove capital controls imposed on banks since the nationalization of several financial institutions. This 
is a significant move in order to normalize relations with foreign markets and it allow firms and domestic businesses to access foreign credit markets.

Graph 9

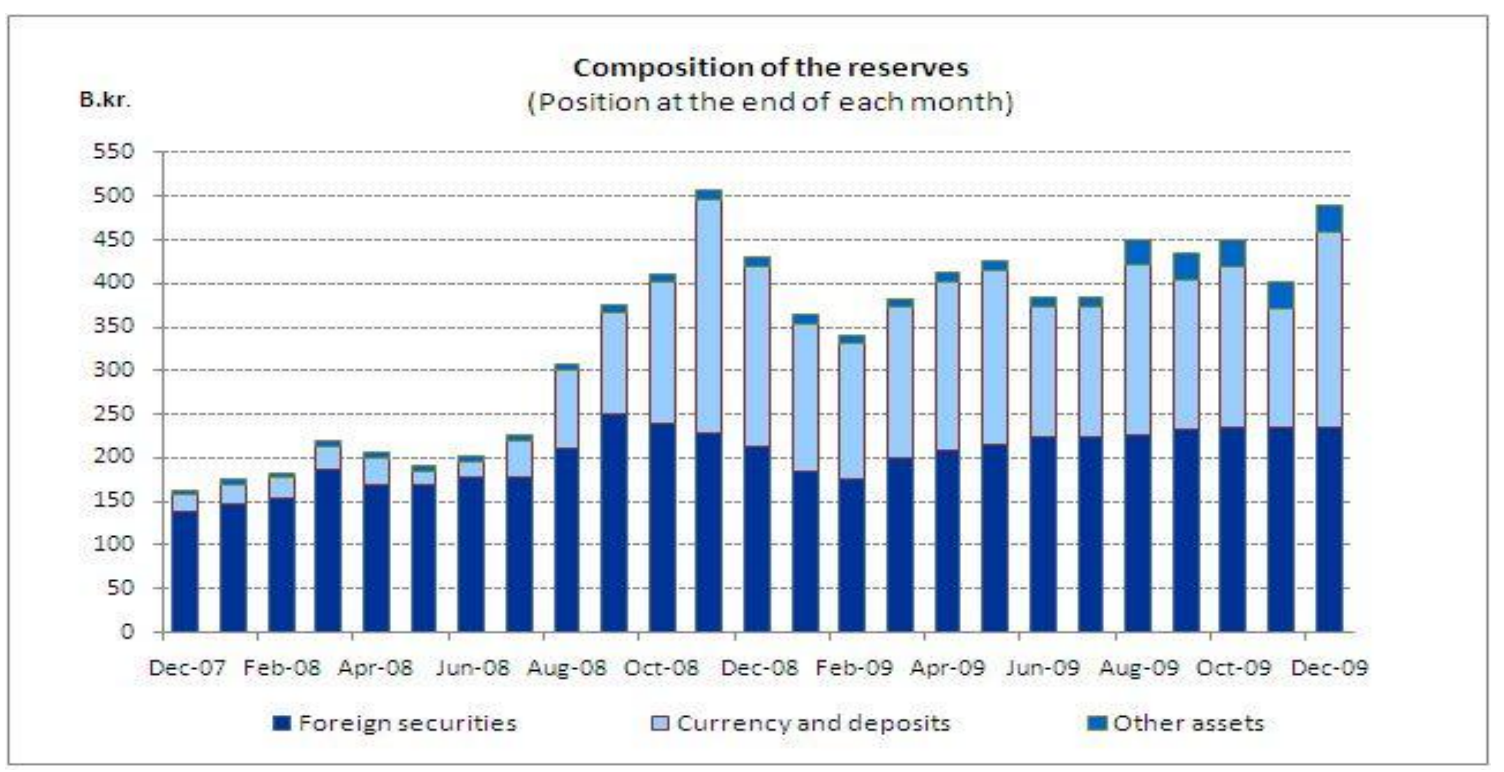

Graph 10

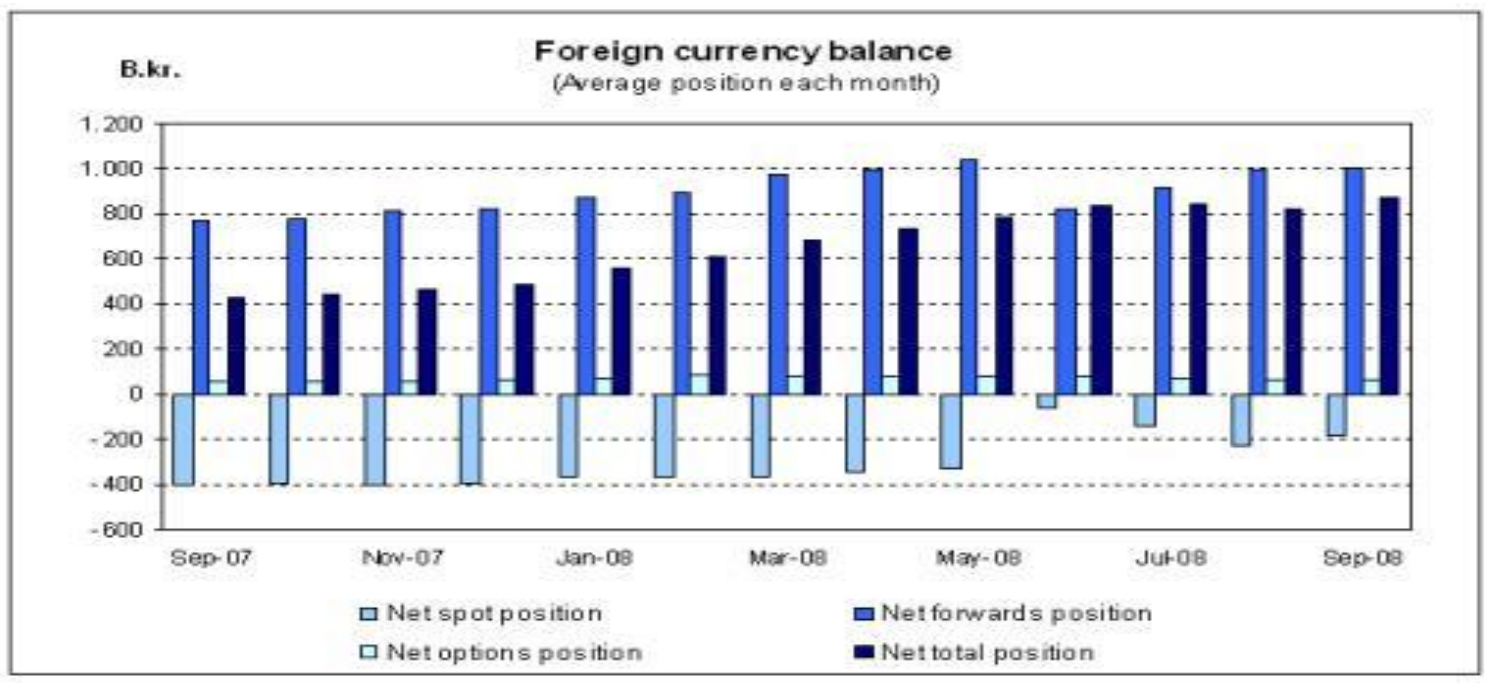




\section{Graph 11}

\section{Quarterly real effective exchange rate \\ 1990/Q1 - 2009/Q4}

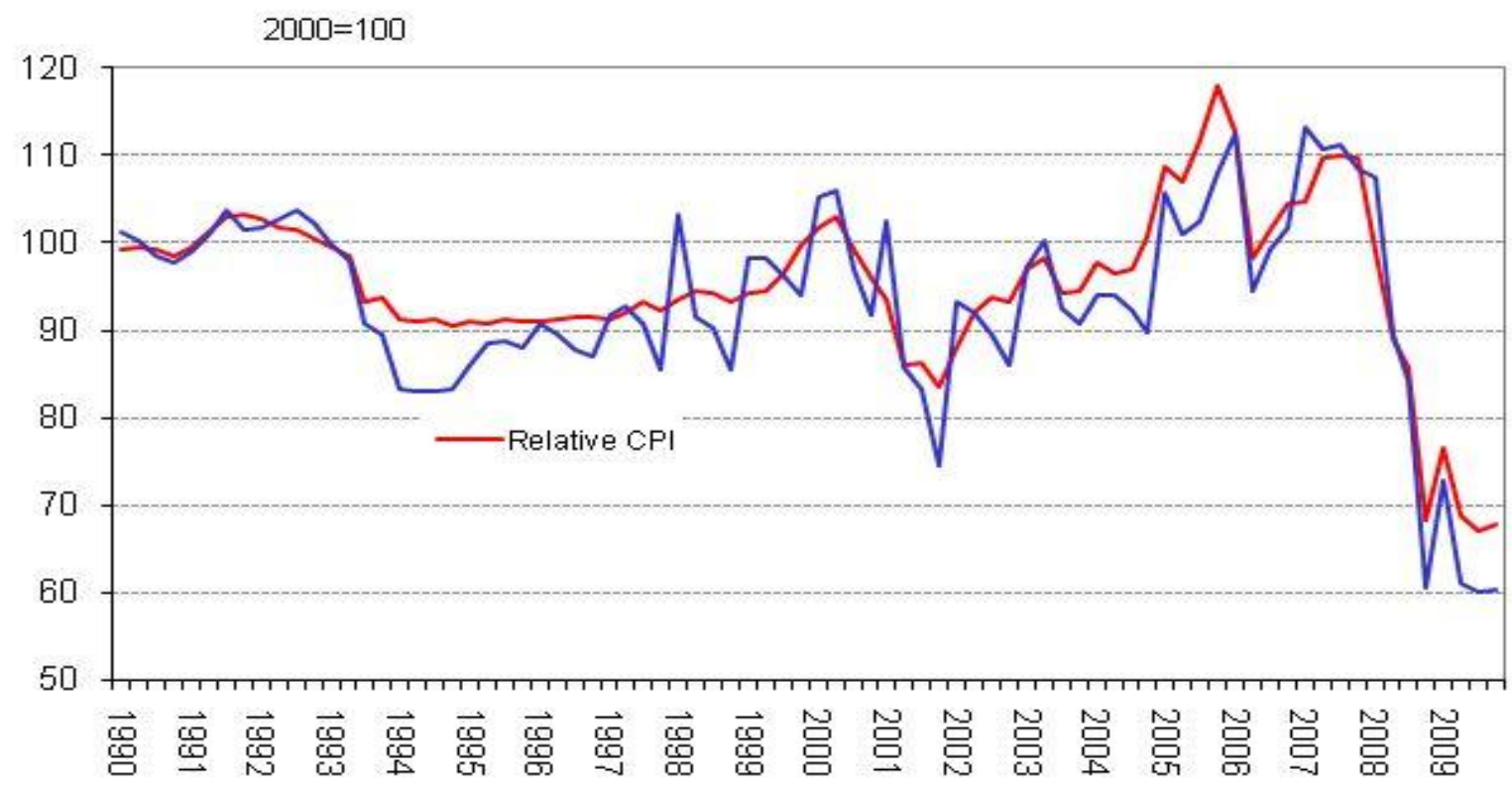

Fortunately, the political environment in Iceland is stable and the government has partnered with IMF to devise medium term policies that could address economic problems facing the country. Faced with an unprecedented crisis, the Icelandic government requested IMF to help and agreed to a program under "Stand by Arrangement". In the short term, the program seeks to prevent further depreciation of the Króna to reduce the risk of adverse effects on the country's balance sheet. Such a risk primarily arises from the high shares of foreignexchange denominated debt in the economy. Hence, the program may end up in a tighter monetary policy to make Króna assets seem lucrative to investors and for the exchange controls to continue on the capital account.

Another big problem that Iceland faces is the uncertainty of the intrinsic value of a few financial institutions, including the three new banks that were formed after the solvency of the old giants. The monetary authorities have been trying to lay out frameworks that can address the complex nature of the financial system and normalize their operation in sync with domestic growth prospects. The banking system in Iceland has taken a big hit in terms of credibility in international markets and almost the whole system has been downgraded by international credit agencies. The liquidity issue must be addressed in order for the capital to find its way back to the business.

The Icelandic government imposed two types of capital controls in response to the capital crisis. First, they put measures in place to prevent outflow of foreign reserves causing downward pressure on the exchange rates of the Krona. The outflow would have resulted from the nonresident investors who had large holdings of the Kronadominated assets which would have been dumped in the market, further hurting the value of the Krona. In addition, the government temporarily disallowed investment abroad which forced the lenders to make funds available to domestic borrowers, thus lowering the risk of uncontrolled interest rate hikes.

Even so, the lack of credit flow and the inability of the government to secure large amounts of external debt have forced interest rates to be unusually high. The biggest challenge facing the monetary authorities is to break the credit freeze and prevent capital flight while lifting the controls on the capital account. The best way forward is for Iceland to seek entry into the euro-zone in order to reap economic benefits, such as access to capital through participating in the credibility of the euro-area monetary system. This can have a stabilizing impact in terms of 
lowering interest rates which can then reduce the government's debt servicing costs, ease balance sheet adjustment for the private sector, and lower the cost of capital to the private sector. However, inclusion in the euro-area monetary system requires accession in the European Union. The macroeconomic conditions for entry into the EU, such as low inflation, a stable exchange rate and low deficits and debt will pose a difficult policy challenge for Iceland in coming years. Nonetheless, this marks the right move considering the stabilizing effects that EU membership can bring to Iceland's shaky economic ground.

\section{THE INTEREST RATE PARITY: REGRESSION ANALYSIS}

The Icelandic economic growth in the last decade has been a function of money borrowed in the international markets. Higher interest rates were one reason why lenders pumped so much money into the system. I was interested in finding a causal relationship between interest rates and the exchange rate for the Icelandic Krona. Regression Model 1 was conducted by collected data on three years' daily interest rates as well as exchange rates from February of 2007 until now.

\section{Model 1}

\section{THE SAS SYSTEM}

The REG Procedure

Model: MODEL 1

Dependent Variable: ExRate ExRate

$\begin{array}{lll}\text { Number of Observations Read } & 802 \\ \text { Number of Observations Used } & 766 \\ \text { Number of Observations with Missing Values } & 36 & \end{array}$

Analysis of Variance

\begin{tabular}{lrrrrr} 
Source & DF & $\begin{array}{l}\text { Sum of } \\
\text { Squares }\end{array}$ & $\begin{array}{l}\text { Mean } \\
\text { Square }\end{array}$ & F Value & Pr > F \\
\hline Model & 1 & 51153 & & & \\
Error & 764 & 556801 & 728.7969 & 70.19 & $<.0001$ \\
Corrected Total & 765 & 607954 & & &
\end{tabular}

$\begin{array}{llll}\text { Root MSE } & 26.99624 & \text { R-Square } & 0.0841 \\ \text { Dependent Mean } & 92.81812 & \text { Adj R-Sq } & 0.0829 \\ \text { Coeff Var } & 29.08510 & & \end{array}$

Parameter Estimates

\begin{tabular}{lllllll} 
& & \multicolumn{2}{c}{ Parameter } & Standard & Pr $>|\mathbf{t}|$ \\
Variable & Label & DF & Estimate & Error & t Value & \\
Intercept & Intercept & 1 & 39.26807 & 6.46583 & 6.07 & $<.0001$ \\
InterestRates & InterestRates & 1 & 3.27814 & 0.39128 & 8.38 & $<.0001$
\end{tabular}




\section{Graph 12}

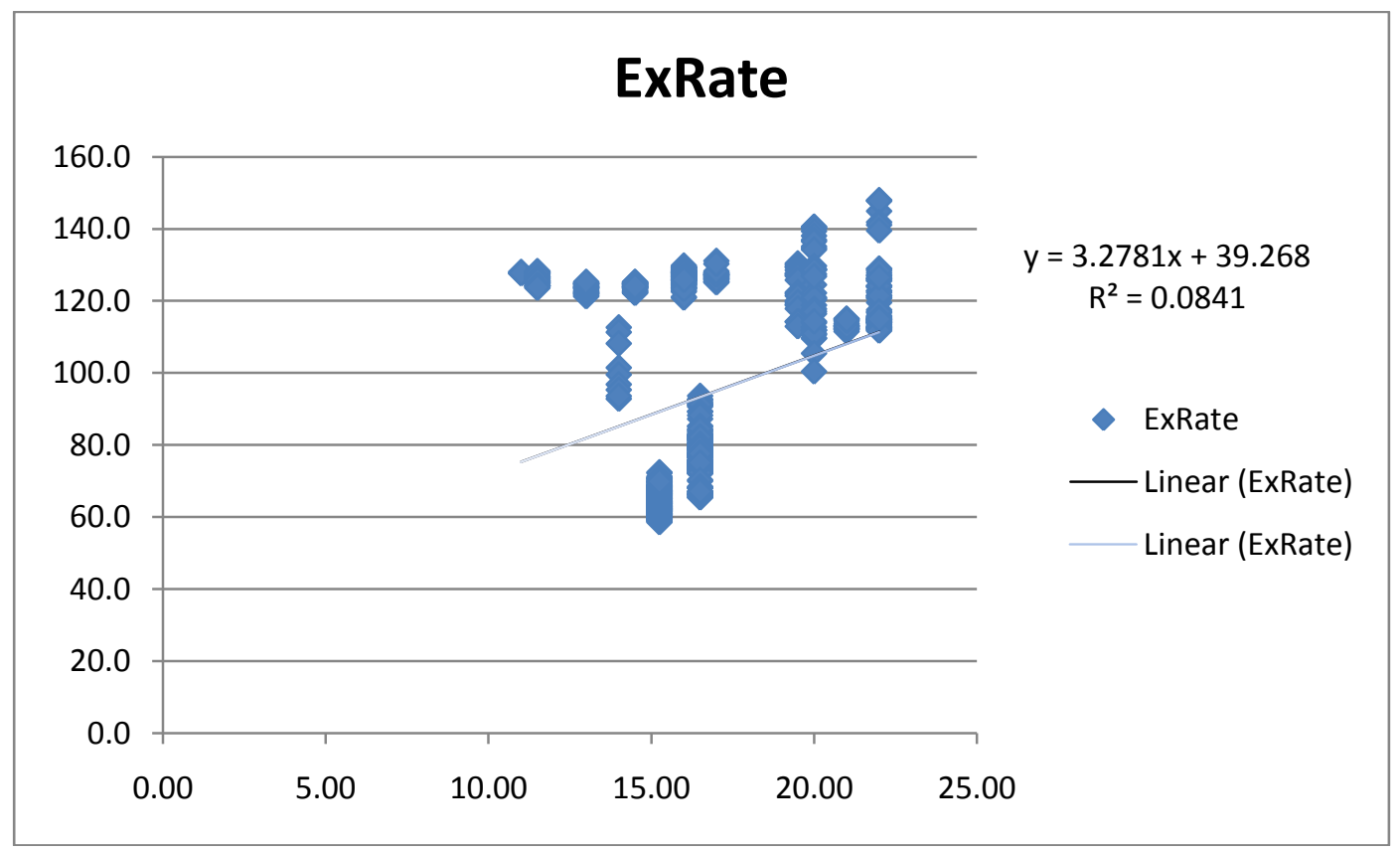

If we look deeper into the Graph 12 and then compare the findings with the regression model, the conclusions are contradictory. According to the graph that was also generated using the same data as used in the model, the exchange rate for the Krona seems to have a negative correlation with interest rates. In other words, as interest rates increase, the Krona depreciates. This does not make much intuitive sense because the truth of the case is that as interest rates increase, more international reserves become available, hence shortening the supply of the Krona relative to other international currencies. This should naturally lead to appreciating trend in the Krona.

This finding is also supported by our model. The relationship between the interest rates and the Krona, as indicated by the model, is, in fact, statistically insignificant because of a very low p-value. In addition, our unusually low R-sq statistic indicates that very little variation in our dependant variable is explained by our independent variable which would be interest rates in this case.

Exchange rates are influenced by hundreds of factors as well as their combinations. Therefore, a model that is based on a few numbers of explanatory variables will fail to explain much.

\section{LOOKING FORWARD}

The future of Icelandic currency depends very much on the overall economic conditions inside the country, as well as the recovery of the global economy. The stability of the financial system, the balance of debt to equity, the flow of international capital and, finally, economic expansion in more than one sector, are main determinants of future exchange rates with respect to the Krona. The amount of information and economic literature that is publicly available on the Icelandic economy concludes the following:

- $\quad$ The financial system has been the backbone of the Icelandic economy since the early 2000s. Therefore, it is necessary that the government, through partnership with the IMF, take measures to stabilize financial institutions. Banks must be capitalized in order for the credit to flow to households and businesses. In the meantime, necessary regulatory reform must take place to prevent another financial crisis. 
- $\quad$ As soon as the economy shows signs of recovery, the government must take measures to curb deficit and external debt. This is a challenging task because early curbs on spending can hurt the process of recovery to the extent that government stimulus programs contribute to the recovery.

- The Icelandic banking system has been badly hurt and downgraded. In order to attract international capital, the interest must increase to compensate for the relevant risk inherent in the system. The kind of capital that used to come from overseas sources will most probably not be available again both due to a destabilized credit system and shrinking capital markets around the globe. Therefore, Iceland may have to depend on domestic capital to finance its growth.

- $\quad$ The economy must diversify. Big investments are taking place in energy sectors as well as the export of aluminum. The fishing industry must be revived as part of overall efforts to create jobs.

- $\quad$ Iceland must do its best to join the Euro zone. This will enable the country to gain access to capital through European financial markets as well as expand markets for its exports. In the long run, the country might be able to switch to the Euro as its national currency.

\section{CONCLUSION}

At this point, my economic outlook on the financial system in Iceland is negative. The banks are undercapitalized and overregulated. In the meantime, the government is finding it difficult to secure loans from global financial markets and institutions, such as the IMF. There are signs of recovery; however, the overall economy is at its most fragile stage. Unemployment is expected to increase throughout 2010 before dropping in 2011. The credit freeze shows no indication of ending anytime soon. The value of the Krona is tied to all of the above-mentioned variables, and right now all of those variables are moving in the opposite direction. Therefore, my recommendation with regard to trading of the Krona is to sell for people who have a short-term investment horizon. However, in the long-term ranging from three to five years, the currency promises a modest return. Even so, the economic outlook seems less than impressive to me while carrying a great amount of risk. Hence, my current position is to stay away from trading in the Krona and, at best, I would go about shorting a small amount of the currency.

\section{AUTHOR INFORMATION}

Dr. Merouane Lakehal-Ayat is a full Professor at St. John Fisher College, Rochester, New York. He has taught at St. John Fisher College since 1986. Dr. M. Lakehal-Ayat holds a PhD in International Finance and Economics, MBA (Finance) and Masters in International Management, and Economics from the University of Denver-Colorado and a JD and BSBA from the University of Algiers-Algeria. Dr. Merouane Lakehal-Ayat was awarded Fulbright Fellowships to Malaysia, Poland and Thailand during the 2001 to 2009 period. He is presently a Visiting Fellow at UTM Malaysia.

\section{REFERENCES}

1. Forex.com. Forex, 25 Dec. 2010. Web. 25 Dec. 2009 <http://Forex.com $>$.

2. Wsj.com. Wallstreet Journal, 25 Dec. 2010. Web. 25 Dec. $2009<$ http://wsj.com $>$.

3. Central Bank of Iceland. Central Bank of Iceland, 26 Nov. 2009. Web. 28 Dec. 2009

<http://www.sedlabanki.is/?pageid=194>

4. OECD. Organization for Economic Co-operation and Development, 26 Nov. 2009. Web. 10 Jan. 2010

< http://www.oecd.org/country/0,3377, en 33873108 33873476 1 11 1 1 1 1 1, 1,00.html >.

5. IMF-Iceland. International Monetary Fund, 4 Jan. 2010. Web. 8 Jan. 2010

<http://https://www.imf.org/external/country/ISL/index.htm $>$. 